University of Nebraska - Lincoln

DigitalCommons@University of Nebraska - Lincoln

Faculty Papers and Publications in Animal

Science

Animal Science Department

January 1973

\title{
GENETIC ASPECTS OF BEEF PRODUCTION AMONG HOLSTEIN- FRIESIANS PEDIGREE SELECTED FOR MILK PRODUCTION
}

\author{
L. L. Calo \\ East-West Food Institute, Honolulu, Hawaii \\ R. E. McDowell \\ Cornell University \\ L. Dale Van Vleck \\ University of Nebraska-Lincoln, dvan-vleck1@unl.edu \\ P. D. Miller \\ American Breeders Service, Inc., DeForest, Wisconsin
}

Follow this and additional works at: https://digitalcommons.unl.edu/animalscifacpub

Part of the Animal Sciences Commons

Calo, L. L.; McDowell, R. E.; Van Vleck, L. Dale; and Miller, P. D., "GENETIC ASPECTS OF BEEF PRODUCTION AMONG HOLSTEIN-FRIESIANS PEDIGREE SELECTED FOR MILK PRODUCTION" (1973). Faculty Papers and Publications in Animal Science. 330.

https://digitalcommons.unl.edu/animalscifacpub/330

This Article is brought to you for free and open access by the Animal Science Department at DigitalCommons@University of Nebraska - Lincoln. It has been accepted for inclusion in Faculty Papers and Publications in Animal Science by an authorized administrator of DigitalCommons@University of Nebraska - Lincoln. 
Calo, L. L., R. E. McDowell, L. D. Van Vleck and P. D. Miller. 1973. Genetic aspects of beef production among Holstein-Friesians pedigree selected for milk production. Journal of Animal Science, 37:676-682.

Abstract: To explore the potential of cattle to produce both milk and beef, the genetic aspects of beef production among Holstein-Friesian bulls pedigree selected for milk were studied. The data included growth records of 504 bulls (DPT) by 120 sires (SPT) pedigree selected for progeny testing by American Breeders Service, 1964 to 1971. DPT bulls with proofs had an average predicted difference for milk (PMD) of +180 kilograms. The daughter average was $7,273 \mathrm{~kg}$ per lactation under varying herd conditions. Sires accounted for $10 \%$ of the variation in average daily gain (ADG), 10\% in daily gain per $100 \mathrm{~kg}$ body weight (DG/100) and 16\% in body weight, indicating substantial genetic variability in beef traits. Sire variance components for beef traits varied with age. There were wide ranges in estimated breeding value (EBV) and estimated transmitting ability (ETA) for beef traits among DPT and SPT bulls, respectively. Ranking EBV among DPT bulls and ETA among SPT bulls for beef traits and selecting the top 10\% and 20\%, respectively, showed high selection differentials, empirically reflecting the potential for genetic improvement from selection.

Copyright $\odot 1973$ American Society of Animal Science. Used by permission. 


\title{
GENETIC ASPECTS OF BEEF PRODUCTION AMONG HOLSTEIN-FRIESIANS PEDIGREE SELECTED FOR MILK PRODUCTION ${ }^{1}$
}

\author{
L. L. Calo, ${ }^{2}$ R. E. McDowell, ${ }^{3}$ L. D. VanVleck ${ }^{3}$ and P. D. Miller ${ }^{4}$ \\ Cornell University, ${ }^{3}$ Ithaca New York 14850
}

\section{Summary}

$\mathrm{T}$ explore the potential of cattle to produce both milk and beef, the genetic aspects of beef production among Holstein-Friesian bulls pedigree selected for milk were studied. The data included growth records of 504 bulls (DPT) by 120 sires (SPT) pedigree selected for progeny testing by American Breeders Service, 1964 to 1971 . DPT bulls with proofs had an average predicted difference for milk (PMD) of +180 kilograms. The daughter average was $7,273 \mathrm{~kg}$ per lactation under varying herd conditions.

Sires accounted for $10 \%$ of the variation in average daily gain (ADG), $10 \%$ in daily gain per $100 \mathrm{~kg}$ body weight $(\mathrm{DG} / 100)$ and $16 \%$ in body weight, indicating substantial genetic variability in beef traits. Sire variance components for beef traits varied with age. There were wide ranges in estimated breeding value (EBV) and estimated transmitting ability (ETA) for beef traits among DPT and SPT bulls, respectively.

Ranking EBV among DPT bulls and ETA among SPT bulls for beef traits and selecting the top $10 \%$ and $20 \%$, respectively, showed high selection differentials, empirically reflecting the potential for genetic improvement from selection.

Average genetic correlations of milk production with beef traits ranged from 0.02 to 0.28 for body weight, from 0.02 to 0.26 for $\mathrm{ADG}$, and from 0.01 to 0.20 for $\mathrm{DG} / 100$. Genetic correlations between milk and beef traits were low but positive, indicating emphasis could be shifted to either milk or beef without adverse effect on the other.

Holstein-Friesians pedigree selected for milk

\footnotetext{
1 The authors wish to acknowledge the cooperation of the
American Breeders Service, Inc., DeForest, Wisconsin for mak-

American Breeders Service, Inc., DeForest, Wisconsin for mak 96822 .

3 Department of Animal Science.

- Present address: American Breeders Service, Inc., DeForest, Wisconsin 53532 .
}

have not only a high capacity to produce beef but also have potential for genetic improvement in beef production. Selection for beef could be incorporated into the existing dairy herd improvement program and the U.S. Holstein-Friesians could be improved to produce milk, beef and total protein.

\section{Introduction}

Cattle have been a major source of milk and meat for man; however, with increasing human population the existing separate specialized systems of production for milk and beef may not continue feasible in the future. Rising land values, limited land areas available for food production and other accompanying economic forces will likely compel cattle producers to adopt a more efficient system of production than currently employed.

Genetic progress in cattle is slow and with the increasing urgency of the world's need for high quality protein, cattle breeders should intensify their efforts to develop a highly efficient milk-beef herd for the future. The feasibility of this approach will depend on the genetic merits for beef among animals high in milk production. The purpose of this study was to assess the genetic variability for beef production as well as the genetic relationship between beef and milk traits among HolsteinFriesian bulls pedigree selected for milk production.

\section{Materials and Methods}

The data included 8,412 body weights for 504 Holstein-Friesian bulls (DPT) by 120 sires (SPT) that were selected for progeny testing by American Breeders Service (ABS) from 1964 to 1971 . The feeding and management procedures were presented by Calo $e t a l$. (1973a).

To estimate sire effects on beef traits, the 
growth records for the DPT bulls were sorted into 120 sire groups and 19 contemporary groups. A contemporary group consisted of animals bought to the ABS center within a 3-month period. Maternal effects on growth were treated as random, since the calves were removed from the dam 3 days after birth, and so were other environmental effects prior to the bulls entering the center. The model employed to describe the analysis was:

$Y_{i j k}=\mu+S_{i}+C G_{j}+e_{i j k}$, where

$\mathbf{Y}_{\mathrm{ijk}}=$ the measure of the $k$ th progeny of the $i$ th sire in the $j$ th group,

$\mu=$ the overall population mean,

$S_{1}=$ the effect of the $i$ th sire,

$\mathrm{CG}_{\mathrm{j}}=$ the effect of the $j$ th contemporary group, and

$e_{i j k}=$ the random effects associated with the $k$ th progeny of the subclasses (ij), where $e_{i j k}, S_{i}$ and $C_{j}$ are assumed to be independently distributed random variables with mean zero and variances $\sigma_{\mathrm{e}}^{2}, \sigma_{\mathrm{s}}^{2}$, and $\sigma_{\mathrm{CQ}}^{2}$, respectively.

Components of variance due to sire, contemporary groups and error for beef traits were estimated by Method 1 described by Henderson (1953). Sums of squares for the analysis of variance were computed, then equated to their expectations and solved for the components of variance. Each variance component was also expressed as percentage of the total.

Beef traits studied were body weight at ages $9,12,15,18,24,30,36$ and 60 months; average daily gain (ADG) and daily gain per 100 $\mathrm{kg}$ body weight (DG/100) at age ranges 6 to 9,9 to 12,12 to 15,15 to 18,18 to 24 and 24 to 30 months.

Two groups were evaluated for beef production, DPT bulls based on their own performance and SPT bulls based on the performance of their sons (DPT bulls). Values for DPT bulls were expressed as deviations from contemporary group means. These were weighted by heritabilities of the traits to obtain estimated breeding values (EBV). The average progeny deviation from their contemporary group mean for each SPT bull was weighted by the factor $\frac{\mathrm{Ph}^{2}}{4+(\mathrm{P}-1) \mathrm{h}^{2}}$ to estimate the transmitting ability (ETA) of the SPT bulls for beef traits, where $P$ was the number of progeny of the sire considered and $h^{2}$ was the heritability estimate. Heritability values used were 0.50 for growth rate and 0.55 for body weight. The DPT and
SPT bulls were ranked according to both their EBV and ETA for beef production.

Predicted differences for milk yield obtained from the USDA-DHIA Sire Summary Lists of 1965 through 1971 were used for determining the genetic relationship between milk and beef traits as follows: 197 DPT bulls with first proof, 161 DPT with latest proof, and 111 SPT bulls with latest proof. The milk proofs for DPT bulls were correlated with their respective EBV for beef traits at different age levels. Likewise, the milk proof for each EPT bull was correlated with his respective ETA for beef traits.

Since the simple correlation $\left(r_{M B}\right)$ between EBV for milk and EBV for beef or between ETA for milk and ETA for beef does not reflect fully the genetic relationship between the two traits, adjustments were made to approximate the genetic correlations. The steps involved in the adjustment procedure were as follows:

a. $\operatorname{Cov}\left(\mathrm{EBV}_{\mathrm{m}}, \mathrm{EBV}_{\mathrm{B}}\right)$

$=\operatorname{Cov}\left[2 b_{M}\right.$ (Daug. avg Milk Dev.), $b_{B}$ (Bull avg Dev.)]

$=2 b_{M} b_{B} \operatorname{Cov}$ (Daug. avg Milk Dev., Bull avg Dev.)

$=2 \mathrm{~b}_{\mathrm{M}} \mathrm{b}_{\mathrm{B}} \mathrm{r} / 2 \sigma_{\mathrm{G}_{M} \mathrm{G}_{\mathrm{B}}}$

$=\mathrm{b}_{\mathrm{M}} \mathrm{b}_{\mathrm{B}} \sigma_{\mathrm{G}_{M} \mathrm{G}_{\mathrm{B}}}$

( $b_{\mathrm{M}}$ is approximately $\frac{\mathrm{N}}{\mathrm{N}+\sigma^{2}{ }_{\mathrm{eM}} / \sigma^{2}{ }_{\mathrm{sM}}}$ for $h^{2}=0.25, \sigma^{2}{ }_{\mathrm{eM}} / \sigma^{2}{ }_{\mathrm{SM}}=15$ )

b. $\operatorname{Var}\left(E B V_{M}\right)$

$=4 \mathrm{~b}^{2}{ }_{\mathrm{M}} \operatorname{Var}$ (Daug. avg Milk Dev.)

$=4\left(\frac{\mathrm{N}}{\mathrm{N}+15}\right)^{2}\left(\sigma^{2}{ }_{\mathrm{sM}}+\frac{\sigma^{2}{ }_{\mathrm{eM}}}{\mathrm{N}}\right)$

$=4\left(\frac{N}{N+15}\right)^{2}\left(\frac{N+15}{N}\right) \sigma^{2}{ }_{s_{M}}$

$=4 \mathrm{~b}_{\mathrm{M}} \sigma^{2}{ }_{\mathrm{sM}}$

$=\mathrm{b}_{\mathrm{M}} \boldsymbol{\sigma}^{2} \mathrm{GM}_{\mathrm{M}}$

c. $\operatorname{Var}\left(\mathrm{EBV}_{\mathrm{B}}\right)$

$=b^{2}{ }_{B} \operatorname{Var}(B)$, (where: $b_{B}=h^{2}{ }_{B}$ and $\mathrm{B}=$ Bull avg dev.)

$$
\begin{aligned}
& =\mathrm{b}^{2}{ }_{\mathrm{B}}\left(\sigma_{\mathrm{G}_{\mathrm{B}}}^{2}+\sigma_{E_{\mathrm{B}}}^{2}\right) \\
& =\mathrm{h}^{2}{ }_{\mathrm{B}}\left(\frac{\sigma^{2}{ }_{\mathrm{GB}}}{\sigma^{2}{ }_{\mathrm{G}_{\mathrm{B}}}+\sigma^{2} \mathrm{E}_{\mathrm{B}}}\right)\left(\sigma^{2}{ }_{\mathrm{G}_{\mathrm{B}}}+\sigma^{2} \mathrm{E}_{\mathrm{B}}\right) \\
& =\mathrm{h}^{2}{ }_{\mathrm{B} \sigma^{2}{ }_{\mathrm{G}_{\mathrm{B}}}}
\end{aligned}
$$


d. Thus $r_{M B}$

$$
\begin{aligned}
& =\frac{2 b_{M} h^{2}{ }_{B}{ }^{2} / 2 \sigma_{G_{M G B}}}{\sqrt{4 b_{M}{ }^{1} / 4 \sigma^{2}{ }_{G_{M}} h^{2}{ }_{B} \sigma^{2}{ }_{G_{B}}}} \\
& =\sqrt{b_{M}} \sqrt{h^{2}{ }_{B}} \frac{\sigma^{2}{ }_{G_{M G} G_{B}}}{\sqrt{\sigma^{2}{ }_{G_{M}} \sigma^{2}{ }_{G_{B}}}} \\
& =\sqrt{b_{M}} \sqrt{h^{2}{ }_{B}} r_{G_{M B}}
\end{aligned}
$$

The genetic correlations for milk and beef traits were finally estimated using the formula:

$$
\mathrm{r}_{\mathrm{GMB}}=\frac{\mathrm{r}_{\mathrm{MB}}}{\sqrt{\mathrm{b}_{\mathrm{M}}} \sqrt{\mathrm{h}^{2}{ }_{\mathrm{B}}}}
$$

where:

$r_{\mathbf{G}_{M B}}=$ the genetic correlation between milk production and beef traits.

$b_{M}=$ the weighting factor for estimating EBV for milk production (avg of repeatability values for milk production of each sire from USDA-DHIA Sire Summary List).

$\mathrm{h}^{2}{ }_{\mathrm{B}}=$ the heritability for beef trait used as the weighting factor for estimating EBV for beef.

The correlations between ETA values for milk production and ETA values for beef were used to estimate genetic relationship for the traits among sires of DPT bulls. Essentially the same procedure was followed for EBV except that the weighting factor for estimating ETA for beef production was $\left(\frac{\mathrm{Ph}^{2}}{4+(\mathrm{P}-1) \mathrm{h}^{2}}\right)$ and the estimate for genetic correlation was:

$$
\mathrm{r}_{\mathrm{G}_{\mathrm{MB}}}=\frac{\mathrm{r}_{\mathrm{MB}}}{\sqrt{\mathrm{b}_{\mathrm{M}}}} \frac{\mathrm{Ph}^{2}}{\sqrt{\frac{4+(\overline{\mathrm{P}}-1) \mathrm{h}^{2}}{n^{2}}}}
$$

\section{Results and Discussion}

Partitioning of Variance. The percentage of total variance for sire and contemporary group for $\mathrm{ADG}$ and $\mathrm{DG} / 100$ are in table 1 and for body weight in table 2 . Sire contribution to variance in the three beef traits varied widely with age. Sire effects on ADG and DG/ 100 were relatively high at early ages, declined to zero at 12 to 15 months and rose to $10 \%$ in later ages (table 1 ).

The sire variance component for body weight was nil at 9 months; it peaked to about $24 \%$ from 18 to 30 months but declined to around $16 \%$ at later ages (table 2 ). The trend was the opposite of that for the other two
TABLE 1. CONTRIBUTION OF SIRE AND CONTEMPORARY GROUP, IN PERCENT, TO TOTAL VARIANCE FOR GROWTH RATE IN HOLSTEIN-FRIESIAN CATTLE PEDPEDIGREE SELECTED FOR MILK

\begin{tabular}{ccccc}
\hline $\begin{array}{c}\text { (Age) } \\
\text { (months) }\end{array}$ & $\begin{array}{c}\text { Total } \\
\text { variance }\end{array}$ & Sire & $\begin{array}{c}\text { Contem- } \\
\text { porary } \\
\text { group }\end{array}$ & Error \\
\cline { 3 - 5 } & \multicolumn{5}{c}{$\%$} \\
ADG (Average daily gain) & \\
$6-9$ & 0.0669 & 16 & 8 & 76 \\
$9-12$ & 0.3945 & 22 & 2 & 76 \\
$12-15$ & 0.0658 & -1 & 12 & 89 \\
$15-18$ & 0.0826 & 2 & 2 & 96 \\
$18-24$ & 0.0868 & 10 & 30 & 60 \\
$24-30$ & 0.0925 & 8 & 14 & 78 \\
Avg & $\ldots \ldots \ldots$ & 10 & 11 & 79
\end{tabular}

DG/100 (daily gain per $100 \mathrm{~kg}$ body weight)

\begin{tabular}{rrrrr}
$6-9$ & 0.0162 & 20 & 9 & 71 \\
$9-12$ & 0.0383 & 20 & 2 & 78 \\
$12-15$ & 0.0038 & -4 & 10 & 94 \\
$15-18$ & 0.0038 & 8 & -1 & 93 \\
$18-24$ & 0.0027 & 6 & 29 & 65 \\
$24-30$ & 0.0020 & 9 & 1 & 90 \\
Avg & $\ldots \ldots$ & 10 & 8 & 82 \\
\hline
\end{tabular}

measures of growth (table 1). It appears there is an age by sire effect interaction that could be important in estimation of sire differences but the cause was not discernible (Calo et al., 1973a). Sampling variance also no doubt affected the magnitude of the components.

Genetic Variability for Beef Traits. The average heritability estimates were $0.44,0.46$ and 0.83 for $A D G, D G / 100 \mathrm{~kg}$ and body weight (Calo et al., 1973a). These heritability values suggest adequate genetic variability for beef traits among animals for genetic improvement through selection (tables 1 and 2).

The possibility of genetic variability for beef traits among bulls of high merit for milk

TABLE 2. CONTRIBUTION OF SIRE AND CONTEMPORARY GROUP, IN PERCENT, TO

TOTAL VARIANCE FOR BODY WEIGHT IN HOLSTEIN-FRIESIAN CATTLE PEDIGREE SELECTED FOR MILK

\begin{tabular}{ccccc}
$\begin{array}{c}\text { (Age) } \\
\text { (months) }\end{array}$ & $\begin{array}{c}\text { Total } \\
\text { variance }\end{array}$ & Sire & $\begin{array}{c}\text { Contem- } \\
\text { porary } \\
\text { group }\end{array}$ & Error \\
\hline & & & $\%$ & \\
9 & 926 & -3 & 9 & 94 \\
12 & 1461 & 14 & 12 & 74 \\
15 & 1894 & 15 & 9 & 76 \\
18 & 2331 & 24 & 2 & 74 \\
24 & 5168 & 24 & 21 & 55 \\
30 & 7934 & 23 & 35 & 42 \\
36 & 9155 & 17 & 35 & 48 \\
60 & 9598 & 16 & 5 & 80 \\
Avg & $\ldots \ldots$ & 16 & 16 & 68 \\
\hline
\end{tabular}


TABLE 3. ESTIMATED GENETIC SUPERIORITY OF THE SELECTED TOP 10 PERCENT OF THE DPT BULLS BASED ON THEIR OWN PERFORMANCE FOR BODY WEIGHTS AT DIFFERENT AGES

\begin{tabular}{|c|c|c|c|c|c|c|c|}
\hline \multirow{2}{*}{$\begin{array}{c}\text { Age } \\
\text { (months) }\end{array}$} & \multicolumn{3}{|c|}{ DPT bull population } & \multicolumn{3}{|c|}{ Selected top 10 percent } & \multirow{2}{*}{$\begin{array}{c}\text { Mean } \\
\text { difference }\end{array}$} \\
\hline & No. & Mean EBV ${ }^{a}$ & $\mathrm{SD}$ & No. & Mean EBV & SD & \\
\hline & \multicolumn{3}{|c|}{$\mathbf{k g}$} & & $\mathrm{kg}$ & +2 & $\mathbf{k g}$ \\
\hline 9 & 212 & 0.10 & 16.89 & 21 & 30.53 & 6.79 & 30.43 \\
\hline 12 & 381 & 0.19 & 20.39 & 38 & 36.40 & 9.95 & 36.21 \\
\hline 15 & 358 & 0.10 & 23.68 & 36 & 40.73 & 13.87 & 40.63 \\
\hline 18 & 270 & 0.10 & 27.35 & 27 & 50.15 & 15.85 & 50.05 \\
\hline 24 & 280 & 0.03 & 36.50 & 28 & 71.98 & 22.21 & 71.95 \\
\hline 36 & 244 & 1.09 & 43.77 & 24 & 85.45 & 26.81 & 84.36 \\
\hline 60 & 132 & 2.51 & 56.26 & 13 & 113.29 & 41.16 & 110.78 \\
\hline
\end{tabular}

a Estimated breeding value.

was further demonstrated when the EBV of bulls and the ETA of SPT bulls for beef were estimated. The range of EBV's for body weight at 15 months ( -90 to $178 \mathrm{~kg}$ ) and ETA's for body weight at 15 months ( -26 to $47 \mathrm{~kg}$ ), as well as the ranges for ADG and $\mathrm{DG} / 100 \mathrm{~kg}$ body weight, indicate ample variation for improvement through selection.

Expected Response to Selection. The DPT bulls were ranked according to their EBV for beef traits and the top 10\% selected. The means and standard deviations for each beef trait of the selected group and the DPT bull population are in tables 3 and 4. The mean difference in EBV for body weight between the two groupings represents the genetic superiority of the selected group, one-half of which empirically reflects the expected genetic improvement through selection. For example, at 15 months, the estimated genetic superiority of the top $10 \%$ was $40.6 \mathrm{~kg}$ (table 3 ), thus, on the average, progeny of these bulls would be expected to exceed contemporaries by 20.3 kilograms. This could be a substantial factor for herds interested in beef production, especially when AI is employed.

The difference in EBV's for ADG ranged from 0.20 to $0.25 \mathrm{~kg}$ per day between 6 and 30 months (table 4), implying that progeny of the selected bulls would be gaining 0.10 to $0.12 \mathrm{~kg}$ more per day than contemporaries up to 30 months of age. For DG/100, the progeny of the top $10 \%$ group would exceed the progeny of average bulls by 0.02 to 0.06 $\mathrm{kg} / \mathrm{day}$.

To further illustrate the likelihood of improvement of beef traits through selection with bulls that had high genetic value for milk, the top $20 \%$ of the SPT bulls were identified. The-difference (table 5) between

TABLE 4. ESTIMATED GENETIC SUPERIORITY OF THE SELECTED TOP 10 PERCENT OF THE DPT BULLS BASED ON THEIR OWN PERFORMANCE FOR GROWTH RATES AT DIFFERENT AGE RANGES

\begin{tabular}{|c|c|c|c|c|c|c|c|}
\hline \multirow{2}{*}{$\begin{array}{c}\text { Age } \\
\text { (months) }\end{array}$} & \multicolumn{3}{|c|}{ DPT bull population } & \multicolumn{3}{|c|}{ Selected top 10 percent } & \multirow{2}{*}{$\begin{array}{c}\text { Mean } \\
\text { difference }\end{array}$} \\
\hline & No. & Mean EBV ${ }^{a}$ & $\mathrm{SD}$ & No. & Mean EBV & SD & \\
\hline & \multicolumn{3}{|c|}{$\longrightarrow \mathrm{kg} / \mathrm{day} \longrightarrow \ldots$} & \multicolumn{3}{|c|}{$\mathrm{kg} / \mathrm{day}$} & $\mathrm{kg}$ \\
\hline \multicolumn{8}{|c|}{ Absolute growth rate } \\
\hline $\begin{array}{r}6-9 \\
9-12 \\
12-15 \\
15-18 \\
18-24 \\
24-30\end{array}$ & $\begin{array}{r}83 \\
308 \\
386 \\
313 \\
300 \\
263\end{array}$ & $\begin{array}{l}0.00 \\
0.00 \\
0.00 \\
0.00 \\
0.00 \\
0.00\end{array}$ & $\begin{array}{l}0.13 \\
0.13 \\
0.11 \\
0.15 \\
0.13 \\
0.15\end{array}$ & $\begin{array}{r}8 \\
31 \\
39 \\
31 \\
30 \\
26\end{array}$ & $\begin{array}{l}0.20 \\
0.24 \\
0.21 \\
0.25 \\
0.21 \\
0.22\end{array}$ & $\begin{array}{l}0.04 \\
0.09 \\
0.06 \\
0.05 \\
0.06 \\
0.10\end{array}$ & $\begin{array}{l}0.20 \\
0.24 \\
0.21 \\
0.25 \\
0.21 \\
0.22\end{array}$ \\
\hline \multicolumn{8}{|c|}{ Daily gain per $100 \mathrm{~kg}$ body weight } \\
\hline $\begin{array}{r}6-9 \\
9-12 \\
12-15 \\
15-18 \\
18-24 \\
24-30\end{array}$ & $\begin{array}{r}83 \\
308 \\
386 \\
313 \\
300 \\
263\end{array}$ & $\begin{array}{l}0.00 \\
0.00 \\
0.00 \\
0.00 \\
0.00 \\
0.00\end{array}$ & $\begin{array}{l}0.06 \\
0.04 \\
0.03 \\
0.03 \\
0.23 \\
0.02\end{array}$ & $\begin{array}{r}8 \\
31 \\
39 \\
31 \\
30 \\
26\end{array}$ & $\begin{array}{l}0.12 \\
0.08 \\
0.05 \\
0.06 \\
0.04 \\
0.04\end{array}$ & $\begin{array}{l}0.03 \\
0.02 \\
0.02 \\
0.02 \\
0.01 \\
0.01\end{array}$ & $\begin{array}{l}0.12 \\
0.08 \\
0.05 \\
0.06 \\
0.04 \\
0.04\end{array}$ \\
\hline
\end{tabular}

a Estimated breeding value. 
TABLE 5. ESTIMATED PROGENY SUPERIORITY OF THE SELECTED TOP 20 PERCENT OF THE SPT BULLS BASED ON PROGENY PERFORMANCE FOR BODY WEIGHT AT DIFFERENT AGES

\begin{tabular}{|c|c|c|c|c|c|c|c|}
\hline \multirow{2}{*}{$\begin{array}{c}\text { Age } \\
\text { (months) }\end{array}$} & \multicolumn{3}{|c|}{ SPT bull population } & \multicolumn{3}{|c|}{ Selected top 20 percent } & \multirow{2}{*}{$\begin{array}{c}\text { Mean } \\
\text { difference }\end{array}$} \\
\hline & No. & Mean ETA ${ }^{a}$ & SD & No. & Mean ETA & SD & \\
\hline & \multicolumn{3}{|c|}{$-\mathrm{kg} \longrightarrow$} & \multicolumn{3}{|c|}{$\longrightarrow \mathrm{kg} \longrightarrow$} & $\mathrm{kg}$ \\
\hline 9 & 68 & 0.02 & 5.06 & 14 & 6.19 & 1.54 & 6.17 \\
\hline 12 & 95 & -.21 & 7.41 & 19 & 9.67 & 3.31 & 9.88 \\
\hline 15 & 100 & -.20 & 8.42 & 20 & 11.32 & 4.89 & 11.52 \\
\hline 18 & 91 & 0.13 & 10.15 & 18 & 14.32 & 4.26 & 14.19 \\
\hline 24 & 91 & 0.27 & 13.43 & 18 & 19.45 & 9.38 & 19.18 \\
\hline 36 & 83 & 0.03 & 15.25 & 17 & 22.53 & 9.29 & 22.50 \\
\hline 60 & 56 & -.22 & 20.29 & 11 & 29.17 & 17.34 & 29.39 \\
\hline
\end{tabular}

a Estimated transmitting ability.

average bulls and the top $20 \%$ reflects the possible variation among SPT bulls. Based on the performance of their progeny at 15 months of age, the progeny of the selected group would be expected to average $11.5 \mathrm{~kg}$ above their contemporaries at 15 months.

While this study indicates substantial response could be expected in selection for beef traits, the feasibility of incorporating selection for beef production into the existing dairy herd improvement program would depend on the nature of genetic relationships between milk and beef traits among Holstein-Friesians. The economic values for meat and milk will be of major concern to dairymen (Calo et al., 1973b).

Genetic Relationships Between Milk and Beef Production Traits. The estimated genetic correlations between milk and beef traits are in tables 6, 7 and 8. The average genetic correlations between milk production and body weights at various ages were low but all positive, ranging from 0.02 to 0.28 (table 6 ). Soller, Bar-Anan and Pasternack (1966) also found a low genetic correlation between milk production and 12-month live weight in Israeli Friesians. In the present study, the correlations were somewhat higher from 9 to 24 months than at 36 and 60 months, indicating body weight in early stages of development is more related to milk production than at 30 months and later. The magnitude of the correlations from 9 to 24 months (table 6) suggests that selection for milk alone would tend to increase body weight.

The average genetic correlations between milk production and average daily gain were also positive, but lower and more variable than for body weight from 6 to 30 months of age (table 7). However, they are within the range given by others, such as between sire progeny test for milk with progeny net gain to slaughter at 10 months of age for 25 German Friesian bulls (Langlet, 1965), 0.22; between contemporary comparison proofs for milk yields of daughters and rate of gain to one year of age of sons of 15 Israeli Friesian sires (Bar-Anan et al., 1965), 0.06; between milk and meat performance of half sibs in German Fleckvieh cattle (Bogner, 1962),

TABLE 6. GENETIC CORRELATIONS BETWEEN MILK PRODUCTION AND BODY WEIGHT AT DIFFERENT AGES

\begin{tabular}{|c|c|c|c|c|c|c|c|}
\hline \multirow[b]{2}{*}{$\begin{array}{c}\text { Age } \\
\text { (months) }\end{array}$} & \multicolumn{2}{|c|}{ Group I ${ }^{a}$} & \multicolumn{2}{|c|}{ Group II $^{\text {b }}$} & \multicolumn{2}{|c|}{ Group III $^{c}$} & \multirow{2}{*}{$\frac{\text { Average }}{\begin{array}{c}\text { Genetic } \\
\text { correlation }\end{array}}$} \\
\hline & No. & $\begin{array}{c}\text { Genetic } \\
\text { correlation }\end{array}$ & No. & $\begin{array}{c}\text { Genetic } \\
\text { correlation }\end{array}$ & No. & $\begin{array}{l}\text { Genetic } \\
\text { correlation }\end{array}$ & \\
\hline 9 & 93 & 0.22 & 71 & 0.33 & 66 & 0.23 & 0.26 \\
\hline 12 & 115 & 0.34 & 87 & 0.16 & 89 & 0.05 & 0.20 \\
\hline 15 & 99 & 0.50 & 77 & 0.22 & 93 & 0.02 & 0.25 \\
\hline 18 & 55 & 0.50 & 39 & 0.21 & 85 & 0.03 & 0.21 \\
\hline 24 & 81 & 0.38 & 56 & 0.31 & 83 & 0.16 & 0.28 \\
\hline 36 & 116 & 0.29 & 85 & -.02 & 76 & -.16 & 0.07 \\
\hline 60 & 94 & 0.27 & 76 & -.04 & 54 & -.34 & 0.02 \\
\hline
\end{tabular}

a DPT bulls first milk production proof correlated with own EBV for body weight.

b DPT bulls latest milk production proof correlated with own EBV for body weight.

c SPT bulls latest milk production proof correlated with corresponding progeny test for body weight for age. 
TABLE 7. GENETIC CORRELATIONS BETWEEN MILK PRODUCTION AND AVERAGE DAILY GAIN AT DIFFERENT AGE RANGES

\begin{tabular}{|c|c|c|c|c|c|c|c|}
\hline \multirow[b]{2}{*}{$\begin{array}{c}\text { Age } \\
\text { (months) }\end{array}$} & \multicolumn{2}{|c|}{ Group I ${ }^{\text {a }}$} & \multicolumn{2}{|c|}{ Group II $^{b}$} & \multicolumn{2}{|c|}{ Group III $^{c}$} & \multirow{2}{*}{$\frac{\text { Average }}{\text { Genetic }}$} \\
\hline & No. & $\begin{array}{c}\text { Genetic } \\
\text { correlation }\end{array}$ & No. & $\begin{array}{c}\text { Genetic } \\
\text { correlation }\end{array}$ & No. & $\begin{array}{c}\text { Genetic } \\
\text { correlation }\end{array}$ & \\
\hline $6-9$ & 65 & 0.31 & 53 & 0.06 & 37 & 0.05 & 0.16 \\
\hline $9-12$ & 100 & 0.06 & 76 & -.04 & 83 & 0.03 & 0.02 \\
\hline $12-15$ & 112 & 0.24 & 86 & 0.18 & 95 & 0.04 & 0.16 \\
\hline $15-18$ & 75 & 0.32 & 59 & 0.22 & 91 & -.28 & 0.05 \\
\hline $18-24$ & 80 & 0.06 & 59 & 0.13 & 88 & -.10 & 0.02 \\
\hline $24-30$ & 89 & 0.35 & 63 & 0.38 & 82 & 0.07 & 0.26 \\
\hline
\end{tabular}

a DPT bulls first milk production proof correlated with own EBV for ADG.

b DPT bulls latest milk production proof correlated with own EBV for ADG.

c SPT bulls latest milk production proof correlated with corresponding progeny test for ADG.

0.13 ; and between progeny tests of daughters for milk and progeny tests of sons for daily gain (Tyler, 1969), 0.05 to 0.27. SamsonHimmelstjerna (1965) found a genetic correlation of zero between milk yield and growth of half sibs.

The average genetic correlations between milk production and daily gain per $100 \mathrm{~kg}$ body weight were also variable, nevertheless most were positive (table 8 ).

Results indicate that genetic relationships between milk production and beef traits, expressed as body weight for age, ADG and DG/100 kg body weight are essentially positive. The low but positive genetic correlations between beef traits and milk yield indicate that selection for either milk or beef production would automatically bring about some improvement in the other trait. There is no certainty, however, that these relationships are high enough to obviate the need for selection for the other trait when one is under selection. What is important is that it gives some assurance there is no distinct antagonism between milk production and beef traits in the Holstein-Friesian. Thus, independent selection for milk would not likely have det- rimental effects on beef traits and vice versa. This means that shifts could be made in selection emphasis to take advantage of economic conditions without serious reduction in the other product.

The results show that Holstein-Friesian bulls pedigree selected for superiority in milk production have the capacity not only to produce beef but also a potential for improvement in beef production as indicated by their genetic variability for beef traits. The positive genetic relationships between milk production and beef traits favor combined production of milk and beef. These advantages of the HolsteinFriesian breed should certainly be considered in countries where both milk and meat are in short supply. It appears that at least some emphasis in selection for beef could be incorporated into the existing DHI program to improve total protein production. The relative genetic progress from simultaneous selection for milk and beef traits with the difference in degrees of emphasis, along with estimated changes in total protein production and economic values, are discussed by Calo et al. (1973b).

TABLE 8. GENETIC CORRELATIONS BETWEEN MILK PRODUCTION AND DAILY GAIN PER $100 \mathrm{KG}$ BODY WEIGHT AT DIFFERENT AGE RANGES

\begin{tabular}{|c|c|c|c|c|c|c|c|}
\hline \multirow[b]{2}{*}{$\begin{array}{c}\text { Age } \\
\text { (months) }\end{array}$} & \multicolumn{2}{|c|}{ Group I } & \multicolumn{2}{|c|}{ Group II } & \multicolumn{2}{|c|}{ Group III $^{c}$} & \multirow{2}{*}{$\frac{\text { Average }}{\text { Genetic }}$} \\
\hline & No. & $\begin{array}{c}\text { Genetic } \\
\text { correlation }\end{array}$ & No. & $\begin{array}{c}\text { Genetic } \\
\text { correlation }\end{array}$ & No. & $\begin{array}{c}\text { Genetic } \\
\text { correlation }\end{array}$ & \\
\hline $6-9$ & 65 & 0.30 & 53 & 0.00 & 37 & -.11 & 0.10 \\
\hline $9-12$ & 100 & -.12 & 76 & 0.17 & 83 & -.05 & -.01 \\
\hline $12-15$ & 112 & 0.25 & 86 & 0.21 & 95 & 0.08 & 0.18 \\
\hline $15-18$ & 75 & 0.25 & 59 & 0.15 & 91 & -.27 & 0.01 \\
\hline $18-24$ & 80 & 0.07 & 59 & 0.07 & 88 & -.07 & 0.02 \\
\hline $24-30$ & 89 & 0.31 & 63 & 0.33 & 82 & -.01 & 0.20 \\
\hline
\end{tabular}

a DPT bulls first milk production proof correlated with ow $\mathrm{EBV}$ for DG/100.

D DPT bulls latest milk production proof correlated with own EBV for DG/100.

c SPT bulls latest milk production proof correlated with corresponding progeny test for DG/100. 


\section{Literature Cited}

Bar-Anan, R., U. Levi, A. Shilo and M. Soller. 1965. Progeny testing Israeli-Friesian AI sires for rate vi gain. World Rev. Anim. Prod. 1:53.

Bogner, H. 1962. Zuchtungskunde. 34:424 (as cited by Langlet, J. World Conference on Anim. Prod., Rome, 1963).

Calo, L. L., R. E. McDowell, L. D. VanVleck and P. D. Miller. 1973a. Parameters of growth of Holstein-Friesian bulls. J. Anim. Sci. (In press).

Calo, L. L., L. D. VanVleck, R. E. McDowell and P. D. Miller. 1973b. Simultaneous selection for milk and beef production among U.S. Holstein-Friesians. J. Dairy Sci. 56:1080.

Henderson, C. R. 1953. Estimation of variance and covariance components. Biometrics 9:226.

Langlet, J. 1965. Review of existing knowledge of genetic relationship of meat and milk production with special emphasis on experiments techniques and design. World Rev. Anim. Prod. 1:31.

Samson-Himmelstjerna, D. von. 1965. Correlations between milk yield, fat percentage and weight gain of Oldenburg Black Pied Lowland cattle. Zuchtungskunde. $37: 323$.

Soller, M., R. Bar-Anan and H. Pasternack. 1966. A note on heritability of live-weight-for-age in IsraelFriesian dairy bull calves and its genetic correlation with milk production. Anim. Prod. 8:157.

Tyler, W. J. 1969. Relationship between growth traits and the production of milk and meat. Mimeo. paper presented at the 64th Annu. Meet. of Amer. Dairy Sci. Ass.

USDA-DHIA Sire Summary List, May 1964 to May 1971. 